\author{
L.O. SAKHNO ${ }^{1}$, M.S. SLYETS ${ }^{1,2}$ \\ ${ }^{1}$ Institute of Cell Biology and Genetic Engineering NAS of Ukraine, Kyiv \\ E-mail: sakhno@icbge.org.ua \\ ${ }^{2}$ National Technical University of Ukraine «Kyiv Polytechnic Institute»
}

\title{
SUPEROXIDE DISMUTASE ACTIVITY IN TRANSGENIC CANOLA
}

Superoxide dismutase (SOD) activity was investigated in leaves of transgenic canola plants which expressed heterologous genes of different origin, namely 1) herbicide resistance genes (bar and simultaneously bar and epsps); 2) DesC desaturase gene (desC) of cyanobacterium Synechococcus vulcanus; 3) human interferon $\alpha 2 b$ gene (huIFN- $\alpha 2 b)$; 4) esxA::fbp $B^{\Delta T M D}$ fused gene, encoding ESAT-6 and Ag85b Mycobacterium tuberculosis proteins, inducing immune response against tuberculosis; 5) cyp11A1 gene of cytochrome $P 450_{S C C}$ from bovine adrenal cortex mitochondria. Introduction of herbicide resistance genes as well as desaturase gene of cyanobacterium and mycobacterium's genes did not change leaf SOD activity. At the same time it was shown that cyp $11 A 1$ and huIFN- $\alpha 2 b$ canola have increased leaf SOD activity up 58 and $33 \%$, respectively, compared with control ones in non-stress conditions. It may be a prerequisite for improved resistance of these plants to the stressors of different origin.

Key words: Brassica napus, cyp11A1, desC, epsps, esXA::fbp $B^{\Delta \mathrm{TMD}}$, huIFN- $\alpha 2 b, S O D$.

Introduction. Plant cells are continuously exposed to reactive oxygen species (ROS) generated as byproducts of fatty acid $\beta$-oxidation, photorespiration, and photosynthesis. Environmental conditions such as extreme temperatures and/or water stress, especially in combination with high light intensities, and some pathogens can cause oxidative stress damage by overproduction of ROS. The first enzyme in the detoxifying process is superoxide dismutase (SOD, EC 1.15.1.1). It converts superoxide radicals to hydrogen peroxide.

In recent years, interest has increased in the study of the antioxidant enzyme activities, including SOD, at different stages of plant ontogenesis [13]. The specific features of SOD activity were also studied in different genotypes within one species $[4,5]$.

SOD activity was investigated in mutants and transgenic plants which expressed heterologous sod genes of different origin. Transgenic tobacco plants (Nicotiana tabacum) that expressed a chimeric gene which encoded chloroplast-localized pea $\mathrm{Cu} / \mathrm{Zn}$ -

(C) L.O. SAKHNO, M.S. SLYVETS, 2014
SOD had 3-fold higher SOD activity than control ones [6]. It allowed for increased resistance to high light intensity under low temperature [7]. Alfalfa (Medicago sativa) transgenic plants which displayed the altered levels of SOD were created and identified as possessing enhanced freezing stress tolerance, enhanced drought resistance, and improved biomass production and persistence in field trials [8-10]. Rice (Oryza sativa) plants expressing pea MnSOD under the control of the oxidative stress-inducible SWPA2 promoter in chloroplasts demonstrated reduced electrolyte leakage compared to wild type leaf slices and exhibited less injury, measured by net photosynthetic rate, under drought stress induced by polyethylene glycol 6000 [11]. Chinese cabbage (Brassica campestris L. ssp. pekinensis cv. Tropical Pride) plants which expressed maize $\mathrm{Cu} / \mathrm{ZnSOD}$ in chloroplasts showed the levels of protection from $\mathrm{SO}_{2}$ and salt stress that were moderately improved compared to wild-type plants [12]. The photosynthetic activity of $B$. campestris transgenic plants with two simultaneously expressing heterologous genes $(\mathrm{Cu} / \mathrm{ZnSOD}$ and $C A T$ (catalase)) decreased by only $6 \%$, whereas that of initial plants decreased by $72 \%$ when they were exposed to the high $\mathrm{NaCl}$ salinity $(200 \mathrm{mM})$ for 4 weeks [12]. Overexpression of wheat mitochondrial Mn superoxide dismutase (MnSOD3.1) enhanced transgenic canola (Brassica napus) heat, drought and cold tolerance both under artificial and in the field stress conditions [13]. Transgenic Arabidopsis plants, expressing cytosolic $\mathrm{Cu} / \mathrm{ZnSOD}$ of Potentilla atrosanguinea showed an enhanced tolerance to salt stress during germination, seedling establishment and growth in terms of larger root length, larger rosette area and the higher number of leaves besides the high levels of SOD [14]. Thus, plants characterizing by higher SOD activity are more resistant to abiotic and biotic stresses. They also form larger biomass both in normal and stress conditions. Plants with improved SOD activity have shorter vegetative growth stage and bloom earlier allowing get the harvest in a shorter time. 
Still little is known about the influence of genetic transformation using other target genes on the SOD activity in transgenic plants.

Earlier we created transgenic canola plants with heterologous genes of different origin [15-20]. The aim of the present work was to estimate SOD activity in these plants for future stress testing.

Materials and methods. Plant material. Aseptic spring canola plants (Brassica napus L. var. oleifera DC.) with heterologous genes of different origin were analysed. They carry in their nuclear genomes such foreign genes as: 1) herbicide resistance genes (bar and epsps). Plants were obtained by using cv Kalinovskii (5/44/1, 5/44/2 lines) [15] and Exgold (15/133/9, 15/133/3 lines) [16]; 2) DesC desaturase gene (desC) of cyanobacterium Synechococcus vulcanus. Plants were created by using cv Obreey (18a, 18b lines) [17]; 3) human interferon $\alpha 2 \mathrm{~b}$ gene $(h u I F N-\alpha 2 b)$. Plants were obtained by using cv Magnat (9/125/10, 9/125/20 lines) [18]; 4) esx $A: \because f b p B^{\Delta T M D}$ fused gene, encoding ESAT-6 and Ag85b Mycobacterium tuberculosis proteins, inducing immune response against tuberculosis. Plants were created by using cv Kalinovskii (5/67/4, 5/67/14 lines) [19]; 5) cyp11A1 gene of cytochrome $\mathrm{P} 40_{\mathrm{SCC}}$ from bovine adrenal cortex mitochondria. Plants were created by using cv Mariia (12/93/1a, 12/93/2c lines) [20]. Due to bar gene expression all tested canola plants were resistant to BASTA herbicide treatment in greenhouse conditions. It was used in transformation cassettes as selective marker. Both control and transformed plants were propagated in vitro by grafting and were grown under cultivation conditions (16/8 light/dark photoperiod, $+23{ }^{\circ} \mathrm{C}, 4000-5000$ lux) during four weeks in the Sigma $25 \times 150 \mathrm{~mm}$ test tubes with $15 \mathrm{ml}$ agar-solidified MS medium [21].

The total soluble protein (TSP) content was measured using Bradford method [22]. The extracts from plant leaves were prepared in triple volume of $100 \mathrm{mM}$ Tris/ $\mathrm{HCl}$ buffer, $\mathrm{pH}$ 8.0. The optical density was determined by BioPhotomether Eppendorf, v.1.35 (Germany).

Superoxide dismutase activity. Photochemical oxidation of nitro blue tetrazolium (NBT) method was used for SOD activity determination [23]. Fresh plant material $(100 \mathrm{mg})$ was pounded with $1 \mathrm{ml}$ of Tris- $\mathrm{HCl}$ buffer $(\mathrm{pH} 8.0)$ in mortar and was centrifuged at $13000 \mathrm{~g}\left(4{ }^{\circ} \mathrm{C}\right)$ for $15 \mathrm{~min}$. The supernatant was used for analyses. Formation of formasan (violet color substance) reaction was held in Eppendorf tube $(1.5 \mathrm{ml})$. One tube for each probe was retained in the dark. The others were illuminated with white light lamp (fluorescent lamp T5/G5, model ELI-230A-T5-8W) during 5 min in the thermostat at $23{ }^{\circ} \mathrm{C}$. Null probe had no leaf extract in its composition. In this probe oxidation was complete. Plant extracts could inhibit formasan formation due to SOD activity. The optical density of illuminated probe solution was measured by BioPhotomether Eppendorf (Germany) versus the optical density of dark probe. SOD activity was expressed as relative unit/ $\mathrm{mg}$ protein.

Statistical analysis was performed according to Duncan multiple range test. Differences from control values were significant at $p \leq 0.05$. Three independent experiments were conducted in five replications. There were nine replications for formazan measurement.

Results and discussion. It was found that leaf SOD activity differed within the control (untransformed spring canola of five varieties) plants after four weeks growth in the sigma test tubes with agar-solidified MS medium (Figure). The highest SOD activity was detected for $\mathrm{cv}$ Mariia, it significantly differed from all the tested varieties. The differences in SOD activity were not detected among cvs Exgold, Kalinovskii, Obreey.

No SOD activity differences were shown between the control and transformed $(5 / 44 / 1$, $5 / 44 / 2$ ) plants expressing promotorless bar gene. The product of this gene is an enzyme which acetylates phosphinothricin or demethylphosphinothricin [24]. Bar gene expression is not accompanied by superoxide radical formation. This gene is often used as selectable marker during plant genetic manipulations. We found no data on changes in SOD activity in plants which expressed only bar gene proving plant resistance to herbicides (such as BASTA) with phosphinothricin as active agent.

We did not observe significant distinctions in SOD activity in canola plants $(15 / 133 / 5,15 / 133 / 9)$ expressing bar and epsps genes simultaneously. The latter encodes 5-enolpyruvylshikimate-3-phosphate (EPSP) synthase which catalyzes the chemical reaction: phosphoenolpyruvate +3 -phosphoshikimate $\rightleftharpoons$ phosphate +5 -enolpyruvylshikimate-3-phosphate (EPSP) [25]. Glyphosate-based herbicides, such as Roundup, target the shikimate pathway enzyme 5-enolpyruvylshikimate 3-phosphate (EPSP) 


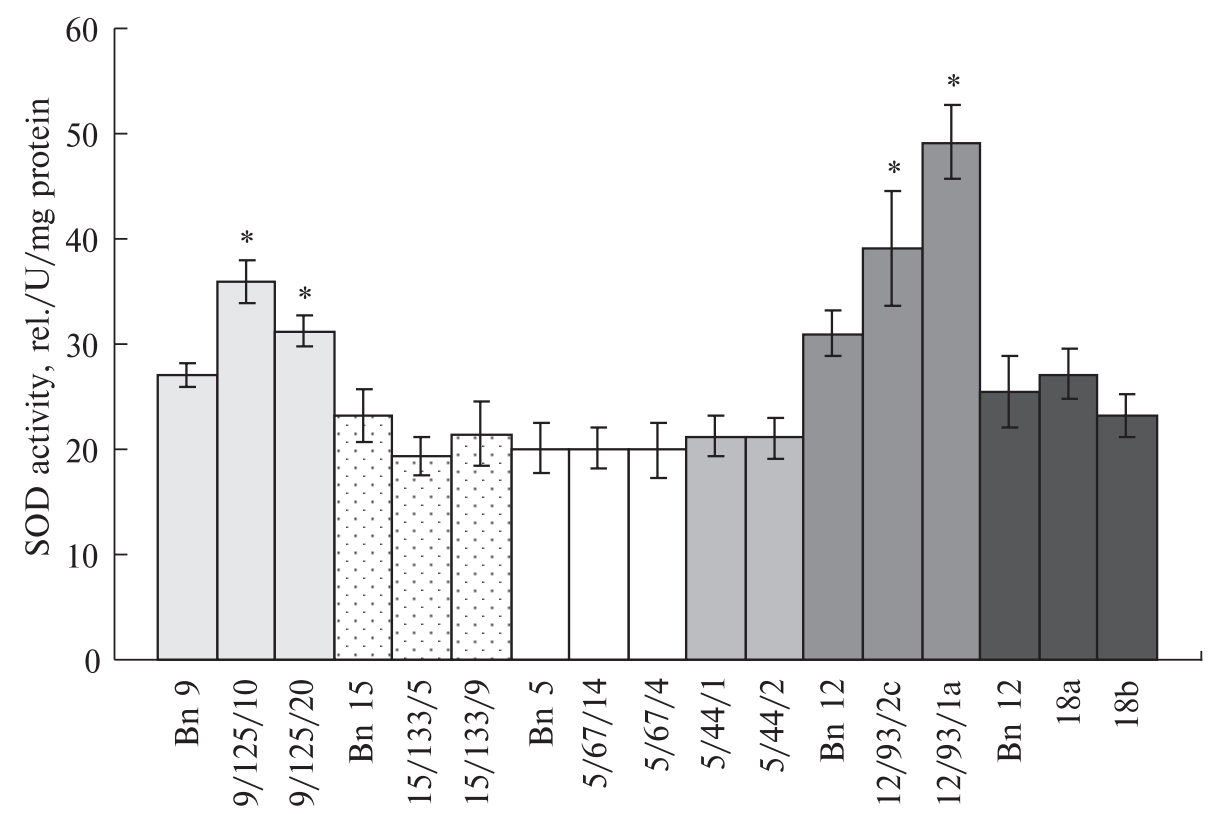

Leaf SOD activity of aseptic canola plants: Bn9, Bn15, Bn5, Bn12, Bn18 were untransformed plants, cvs Magnat, Exgold, Kalinovskii, Mariia, and Obreey, respectively; 9/125/10, 9/125/20 lines expressed human interferon $\alpha 2 b$ gene; 15/133/5, 15/133/9 lines have epsps gene; 5/44/1, 5/44/2 were lines with active promotorless bar gene; 5/67/4, 5/67/14 lines expressed esxA::fbp $B^{\Delta \text { TMD }}$ fused gene; 12/93/1a, 12/93/2c lines carried cyp 11A1 gene; 18a, $18 \mathrm{~b}$ expressed desC of cyanobacterium Synechococcus vulcanus and epsps genes. Error bars represent mean \pm one standard deviation and asterics. * Indicates significant differences between experimental values compared with the control ones $(\mathrm{p} \leq 0.05)$

synthase, the functionality of which is absolutely required for plant survival. Roundup Ready plants carry the gene coding for a glyphosate-insensitive form of this enzyme, obtained from Agrobacterium sp. strain CP4 [26]. Synthase (epsps) expression does not create conditions for $\mathrm{O}_{2}^{-}$formation and SOD activity changes.

Transgenic plants with simultaneously bar, epsps and desC (18a, 18b lines) gene expression have leaf SOD activity similar to control plants (Figure). Fatty acid desaturases catalyze transformation of a single bond between carbon atoms in acyl chains $(\mathrm{C}-\mathrm{C})$ into the double bond $(\mathrm{C}=\mathrm{C})$ [27]. It was shown that des $\mathrm{C}$ expression in transgenic tobacco provides the advantages of these plants under low temperature and their SOD activities increased in stress higher than those of control plants. But under normal condition des $\mathrm{C}$ tobacco SOD activities did not differ in comparison with the wild type plants [28] as well as in our experiments with $B$. napus.

Canola plants expressing simultaneously bar and esxA::fbp $B^{\triangle \mathrm{TMD}}$ fused gene, which encodes ESAT-6 and Ag85b M. tuberculosis proteins (5/67/4, 5/67/14 lines) have the same SOD activities that control plants (Figure). Antigen 85B is a myocolyc transferase in the myc pathway and catalyses the transfer of the fatty acid mycolate from one trehalose monomycolate to another, resulting in trehalose dimycolate and free trehalose and helping build the cell wall [29]. Both $e s x A$ and $f b p B$ gene expression do not cause superoxide radical formation [30].

SOD activities in 12/93/2c (39.1 \pm 5.5$)$ and 12/93/1a (49.11 \pm 3.53$)$ lines were 26 and $58 \%$ higher in comparison with the control one (31.02 \pm \pm 2.06 ). These lines expressed cyp $11 \mathrm{~A} 1$ gene encoding cytochrome $\mathrm{P} 40_{\mathrm{SCC}}$ from bovine adrenal cortex mitochondria [20]. In animals cytochrome $\mathrm{P} 450_{\mathrm{SCC}}$ catalyzes three step cholesterol oxidation with formation of pregnenolone [31, 32]. Superoxide radicals are formed during these reactions. Therefore, SOD activity in cyp $11 \mathrm{~A} 1$ canola can increase due to cytochrome $\mathrm{P}^{4} 50_{\mathrm{SCC}}$ activity.

The SOD activity increase was also detected in the leaves of $h u I F N-\alpha 2 b$ canola plants (Figure). It reached $35.96 \pm 2.1$ (9/125/10 plants), $31.24 \pm 1.5$ 
$(9 / 125 / 20$ line) and $27.02 \pm 1.08$ (control plants). In this group of transgenic canola plants the SOD activity rose up 1.33 fold. Exogenous interferonalpha application is accompanied by superoxide radical formation and SOD activity increase in animal cells $[33,34]$. There are no SOD activity data about the other transgenic plants expressing huIFN gene. We propose that exactly heterologous protein activity (human interferon-alpha) is the reason of the SOD activity increase in our transgenic canola plants.

It was shown that SOD activity in transgenic sod plants increased up to 2.5 (rapeseed) [35], 3 (tobacco) [7], 4 (maize) fold [36] in without stress conditions. We have detected that cyp $11 \mathrm{~A} 1$ and $h u I F N \alpha-2 b$ gene expression can increase leaf SOD activity (up 1.58 and 1.33 fold, respectively). So we found that the SOD activity increase in transgenic plants may be not only due to heterologous sod, but also other target gene expression. Similar results were obtainted in experiments with tomato (Solanum lycopersicum) plants which expressed ZAT12 gene from Brassica carinata encoding a $\mathrm{C}_{2} \mathrm{H}_{2}$ zinc finger transcription factor [37] and arabidopsis (Arabidopsis thaliana) plants expressing TSRfBP (riboflavin-binding protein) gene obtained from the soft-shelled turtle Trionyx sinensis japonicus [38]. The SOD activity was detected to be 1.69 and 1.1 fold higher in leaves of transgenic tomato and arabidopsis plants, respectively, under non-stress conditions in comparison with untransformed ones. Authors have proved drought resistance improvement of these plants in greenhouse [37, 38].

Plants with lower SOD activity were also observed among transgenic plants. It was shown that cherry tomato with $\mathrm{Hbs} \mathrm{Ag}$ (hepatitic B virus) gene had $30 \%$ lower leaf SOD activity in comparison with control one [39]. These plants had higher total soluble protein and relative water content in the leaves, and did not form fertile seeds.

Conclusions. Changes in SOD activity were not observed in desC and esxA::fbp $B^{4 T M D}$ transgenic canola. Leaf SOD activity has not also been affected by introduction of herbicide resistance genes (bar and epsps). However, it was shown that cyp11A1 and huifn- $\alpha 2 b$ canola plants have increased leaf SOD activity up 58 and $33 \%$, respectively, compared with untransformed ones, in nonstress conditions. Increased SOD activity may be a prerequisite for improved resistance of these plants to the stressors of different origin.

Experiments were supported by National Academy of Sciences of Ukraine grants № $0110 U 006061$ and $0110 U 006062$.

\section{Л.А. Сахно, М.С. Сливеи \\ АКТИВНОСТЬ СУПЕРОКСИДДИСМУТАЗЫ В РАСТЕНИЯХ ТРАНСГЕННОГО РАПСА}

Исследована активность супероксиддисмутазы (СОД) в листьях трансгенных растений рапса, экспрессирующих гетерологичные гены различного происхождения, а именно: 1) гены устойчивости к гербицидам (bar и одновременно bar и epsps); 2) ген десатуразы DesC (desC) цианобактерии Synechococcus vulcanus; 3) ген $\alpha 2 \mathrm{~b}$ интерферона человека (huIFN$\alpha 2 b)$; 4) слитый ген esx $:: f b p B^{\wedge \text { TMD }}$, кодирующий белки ESAT-6 и Ag85b Mycobacterium tuberculosis, которые индуцируют иммунный ответ против туберкулеза; 5) ген суp $11 \mathrm{~A} 1$ цитохрома $\mathrm{P} 450_{\mathrm{scc}}$ митохондрий коры надпочечников быка. Введение генов устойчивости к гербицидам, а также гена десатуразы цианобактерии и генов микобактерии не изменяло активности СОД в листьях рапса. Вместе с тем показано, что в условиях без стресса у растений с трансгенами cyp11A1 и $h u I F N-\alpha 2 b$ активность СОД повышена до 58 и $33 \%$ соответственно в сравнении с контролем. Это может быть предпосылкой для увеличения их устойчивости к стрессорам различного происхождения.

\section{Л.О. Сахно, М.С. Сливеиь}

\section{АКТИВНІСТЬ СУПЕРОКСИДДИСМУТАЗИ В РОСЛИНАХ ТРАНСГЕННОГО РІПАКУ}

Досліджено активність супероксиддисмутази (СОД) в листках трансгенних рослин ріпаку, що експресують гетерологічні гени різного походження, а саме: 1) гени стійкості до гербіцидів (bar і одночасно bar i epsps); 2) ген десатурази DesC (desC) ціанобактерії Synechococcus vulcanus; 3) ген $\alpha 2 b$ інтерферона людини $(h u I F N-\alpha 2 b) ; 4)$ злитий ген $\operatorname{esx} A:: f b p B^{\Delta \text { TMD }}$, що кодує білки ESAT-6 і Ag85b Mycobacterium tuberculosis, які індукують імунну відповідь проти туберкульозу; 5) ген сyp11А1 цитохрома $\mathrm{P} 450_{\mathrm{SCC}}$ мітохондрій кори надниркових залоз великої рогатої худоби. Введення генів стійкості до гербіцидів, а також гена десатурази ціанобактерії та генів мікобактерії не змінювало активності СОД в листках ріпаку. Разом з тим встановлено, що у рослин 3 трансгенами суp $11 \mathrm{~A} 1 i h u I F N-\alpha 2 b$ в умовах без стресу активність СОД підвищена до 58 і $33 \%$ відповідно в порівнянні з контролем. Це може бути передумовою для підвищення їхньої стійкості до стресорів різного походження. 


\section{REFERENCES}

1. Diaz-Vivancos P., Barba-Espin G., ClementeMoreno M.J., Hernandez J.A. Characterization of the antioxidant system during the vegetative development of pea plants // Biol. Plant. - 2010. 54, № 1. - P. 76-82.

2. Matamoros M.A., Loscos J., Dietz K.-J. et al. Function of antioxidant enzymes and metabolites during maturation of pea fruits// J. Exp. Bot. 2010. - 61, № 1. - P. 87-97.

3. Shugaev A.G., Lashtabega D.A., Shugaeva N.A., Vyskrebentseva E.I. Activities of antioxidant enzymes in mitochondria of growing and dormant sugar beet roots // Rus. J. Plant Physiol. - 2011. - 58, № 3. P. 387-393.

4. Jin S.H., Li X.Q., Jia X.I. Genotypic differences in the responses of gas exchange, chlorophyll fluorescence, and antioxidant enzymes to aluminium stress in Festuca arundinacea // Rus. J. Plant Physiol. 2011. - 58, № 4. - P. 560-566.

5. Zou $W$., Chen $Y$., Lu C. Differences in biochemical responses to cold stress in two contrasting varieties of rape seed (Brassica napus L.) // For. Stud. China. 2007. - 9, № 2. - P. 142-146.

6. Gupta S.A., Heinen J.I., Holaday A.S. et al. Increased resistance to oxidative stress in transgenic plants that overexpress chloroplastic $\mathrm{Cu} / \mathrm{Zn}$ superoxide dismutase// Proc. Nat. Acad. Sci. USA. - 1993. 90, № 4. - P. 1629-1633.

7. Gupta S.A., Webb R.P., Holaday A.S., Allen R.D. Overexpression of superoxide dismutase protects plants from oxidative stress (induction of ascorbate peroxidase in superoxide dismutase-overexpressing plants) // Plant Physiol. - 1993. - 103, № 4. P. $1067-1073$.

8. McKersie B.D., Bowley S.R., Harjanto E., Leprince O. Water-deficit tolerance and field performance of transgenic alfalfa overexpressing superoxide dismutase // Plant Physiol. - 1996. - 111, № 4. P. 1177-1181.

9. McKersie B.D., Bowley S.R., Jones K.S. Winter survival of transgenic alfalfa overexpressing superoxide dismutase // Plant Physiol. - 1999. - 119, № 3. P. 839-847.

10. Samis K., Bowley S.R., McKersie B.D. Pyramid Mnsuperoxide dismutase transgenes to improve persistence and biomass production in alfalfa // J. Exp. Bot. - 2002. - 53, № 372. - P. 1343-1350.

11. Wang F.-Z., Wang Q.-B., Kwon S.-Y. et al. Enhanced drought tolerance of transgenic rice plants expressing a pea manganese superoxide dismutase // J. Plant Physiol. - 2005. - 162, № 4. - P. 465-472.

12. Tseng M.J., Liu C.-W., Yiu J.-C. Enhanced tolerance to sulfur dioxide and salt stress of transgenic Chinese cabbage plants expressing both superoxide dismutase and catalase in chloroplasts // Plant Physiol. Biochem. - 2007. - 45, № 10/11. - P. 822-833.

13. Gusta L.V., Benning N.T., Wu G. et al. Superoxide dismutase: an all-purpose gene for agri-biotechnology // Mol. Breed. - 2009. - 24, № 2. - P. 103-115.

14. Gill T., Kumar S., Ahuja P.S., Sreenivasulu Y. Over-expression of Potentilla superoxide dismutase improves salt stress tolerance during germination and growth in Arabidopsis thaliana // J. Plant Genet. Transgen. - 2010. - 1, № 1. - P. 1-10.

15. Sakhno L.A., Gocheva E.A., Komarnitskii I.K., Kuchuk N.V. Stable expression of the promotorless bar gene in transformed rapeseed plants // Cytology and Genetics. - 2008. - 42, № 1. - P. 16-22.

16. Sakhno L.A., Komarnitskii I.K., Maistrov P.D., Kuchuk M.V. Creation of glyphosate resistant canola by synthetic epsps gene introduction // Factors of experimental evolution of organisms. - Kyiv : Logos, 2011.- 11. - P. 388-393.

17. Sakhno L.A., Gerasymenko I.M., Komarnitskii I.K. et al. Creation of glyphosate-resistant Brassica napus L. plants expressing DesC desaturase of cyanobacterium Synechococcus vulcanus // Biopolym. Cell. - 2012. 28, № 6. - P. 449-455.

18. Sakhno L.A., Kvasko O.Y., Olevinska Z.M. et al. Creation of transgenic Brassica napus L. plants expressing human alpha $2 \mathrm{~b}$ interferon gene // Cytology and Genetics. - 2012. - 46, № 6. - P. 342-346.

19. Sakhno L.A., Gocheva E.A., Gerasimenko I.M. et al. Introduction of ESAT-6 and Ag85B genes encoding proteins-inductors of immune response against Mycobacterium tuberculosis into rapeseed genome // Plant cell biology in vitro and biotechnology : IX th Int Conf. - Zvenigorod, Russia, 2008. - P. 334335.

20. Sakhno L.O., Morgun B.V., Kvasko O.Y., Kuchuk M.V. Transformed canola plants expressing mammalian cyp11A1 gene of cytochrome $\mathrm{P} 450_{\mathrm{scC}} / /$ Biotechnologia Acta. - 2010. - 3, № 5. - P. 74-82.

21. Murashige T., Skoog F. A revised medium for rapid growth and bioassays with tobacco tissue cultures // Physiol Plant. - 1962. - 15, № 3. - P. 473-497.

22. Bradford M.M. A rapid and sensitive method for the quantitation of microgram quantities of protein utilizing the principle of protein-dye binding // Anal. Biochem. - 1976. - 72, № 2. - P. 248-254.

23. Beyer W.F., Fridovich I. Assaying for superoxide dismutase activity some large consequences of minor changes in conditions // Anal. Biochem. - 1987. 161, № 2. - P. 559-566.

24. Thompson C.J., Movva N.R., Tizard R. et al. Characterization of the herbicide-resistance gene bar from Streptomyces hygroscopius // EMBO J. - 1987. - 6, № 9. - P. 2519-2523.

25. Funke T., Han H., Healy-Fried M.L. et al. Molecular 


\section{Superoxide dismutase activity in transgenic canola}

basis for the herbicide resistance of Roundup Ready crops // Proc. Nat. Acad. Sci. USA. - 2006. - 103, № 35. - P. 13010-13015.

26. WO02/36831 Canola event pv-bngt04(rt73) and compositions and methods for detection thereof / R Krieb, Q. Zeng. - PCT filed October 22, 2001. PCT pub. date May 10, 2002.

27. Los D.A., Murata N. Structure and expression of fatty acid desaturases // Biochim. biophys. acta. - 1998. 1394, № 1. - P. 3-15.

28. Popov V.N., Kipaikina N.V., Astakhova N.V., Trunova T.I. Specific features of oxidative stress in the chilled tobacco plants following transformation with the $\operatorname{des} C$ gene for acyl-lipid $\Delta 9$-desaturase from Synechococcus vulcanus // Rus. J. Plant Physiol. 2006. - 53, № 4. - P. 469-473.

29. Belisle J.T., Vissa V.D., Sievert T. et al. Role of the major antigen of Mycobacterium tuberculosis in cell wall biogenesis // Science. - 1997. - 276, № 5317. P. 1420-1422.

30. Andersen P., Andersen A.B., Surensen A.L., Nagai $S$. Recall of long-lived immunity to Mycobacterium tuberculosis infection in mice // J. Immunol. 1995. - 154, № 7. - P. 3359-3372.

31. Chung B. C., Matteson K. J., Voutilainen R. et al. Human cholesterol side-chain cleavage enzyme, P450scc: cDNA cloning, assignment of the gene to chromosome 15, and expression in the placenta // Proc. Nat. Acad. Sci. USA. - 1986. - 83, № 23. P. 8962-8966.

32. Novikova L.A., Y Faletrov A.V., Kovaleva I.E. et al. From structure and functions of steroidogenic enzymes to new technologies of gene engineering // Biochemistry (Mosc.). - 2009. - 74, № 13. P. 1482-1504.

33. Al-Shabanah O.A., Mansour M.A., Elmazar M.M. Enhanced generation of leukotriene B4 and superoxide radical from calcium ionophore (A23187) stimulated human neutrophils after priming with interferonalpha // Res. Commun. Mol. Pathol. Pharmacol. 1999. - 106, № 1/2. - P. 115-128.

34. Lu G., Shimizu I., Cui X. et al. Interferon-alpha enhances biological defense activities against oxidative stress in cultured rat hepatocytes and hepatic stellate cells // J. Med. Invest. - 2002. - 49, № 3/4. P. 172-181.

35. Basu U., Good A.G., Taylor J. Transgenic Brassica napus plants overexpressing aluminium-induced mitochondrial manganese superoxide dismutase cDNA are resistant to aluminium // Plant, Cell and Environment. - 2001. - 24, № 12. - P. 1269-1278.

36. Kingston A.H., Foyer C.H. Overexpression of Mnsuperoxide dismutase in maize leaves leads to increased monodehydroascorbate reductase, dehydroascorbate reductase and glutathione reductase activities // J. Exp. Bot. - 2000. - 51, № 352. - P. 1867-1877.

37. Rai A.C., Singh M., Shah K. Effect of water withdrawal on formation of free radical, proline accumulation and activities of antioxidant enzymes in ZAT12-transformed transgenic tomato plants // Plant Physiol. Biochem. - 2012. - 61. - P. 108114.

38. Deng B., Dong H. Ectopic expression of riboflavinbinding protein gene $T s R f B P$ paradoxically enhances both plant growth and drought tolerance in transgenic Arabidopsis thaliana // J. Plant Growth Reg. - 2013. 32, № 1. - P. 170-181.

39. Guan Z.J., Guo B., Huo Y.I. et al. Morhpological and physiological characteristics of transgenic cherry tomato mutant with HBsAg gene // Rus. J. Genet. 2011. - 47, № 8. - P. 923-930.

Received 08.04.13 